\title{
1 The Death of (a) Cinema
}

\author{
The State of Things
}

\begin{abstract}
Chapter 1 focuses on Wim Wenders's 1982 The State of Things, a watershed film that distils, in programmatic fashion, the idea of cinema's inherent but unachievable mission to become material reality. The film is located at a significant historical juncture, which marks, on the one hand, the end of the European new waves and new cinemas, and, on the other, Hollywood's move into a self-styled postmodern era, dominated by selfreflexive remakes. More pointedly, it attempts to theorise, in form and content, this cinematic end of history by means of a mise-en-abyme construction evolving across multiple layers of self-referentiality and self-negation, that exposes it to the contingencies of the local environment and improvisations of the characters/actors.
\end{abstract}

Keywords: Wim Wenders; The State of Things; Postmodernism; Remakes; Allusionism; German Cinema

The State of Things (Der Stand der Dinge, Wim Wenders, 1982) constitutes the ideal object with which to initiate this part of the book because it distils, in programmatic fashion, the idea of non-cinema, that is, cinema's inherent but unachievable mission to become material reality. ${ }^{1}$ The film is located at a significant historical juncture, which marks, on the one hand, the end of the European new waves and new cinemas, and, on the other, Hollywood's move into a self-styled postmodern era, dominated by self-reflexive remakes. More pointedly, The State of Things attempts to theorise, in form and content, this cinematic end of history by means of a mise-en-abyme construction evolving across multiple layers of self-referentiality and self-negation. The film starts as a post-catastrophe sci-fi entitled The Survivors, which is interrupted after

1 I have previously elaborated on the idea of 'non-cinema' in Nagib (2016).

Nagib, L., Realist Cinema as World Cinema: Non-cinema, Intermedial Passages, Total Cinema. Amsterdam: Amsterdam University Press, 2020 DOI 10.5117/9789462987517_CHO1 
a few minutes to reveal itself as a film in the making brought to a halt due to the disappearance of its Hollywood producer and the exhaustion of film stock. It then proceeds as a faux documentary of the crew and cast of The Survivors, idly waiting for the shoot to resume on the real locations, a ruined hotel semi-sunken into the sea and its rocky surroundings in the vicinity of Sintra, Portugal. The characters, now donning the mask of actors and technicians, spend their time in the exercise of individual hobbies, such as drawing, painting, playing music, photography, reading, writing and computing, all portrayed as frustrated attempts at capturing and making sense of the real world around them. In the meantime, dialogue lines and voiceovers weave together the film's main declaration of purpose, namely the insufficiency of film, together with all its constitutive artistic and medial forms, to accurately reproduce reality.

With its extensive theorising on the end of the world, the end of cinema and its own failure to deliver a fictional narrative, The State of Things prefigures Fredric Jameson's (2001 [1984]: 188) groundbreaking definition of the postmodern, published just a couple of years later in the article 'Postmodernism, or The Cultural Logic of Late Capitalism':

The last few years have been marked by an inverted millennarianism, in which premonitions of the future, catastrophic or redemptive have been replaced by senses of the end of this or that [...]: taken together, all of these perhaps constitute what is increasingly called postmodernism.

Jameson (188) locates at the origin of this tendency a historical break or coupure, which

is most often related to notions of the waning or extinction of the hundredyear-old modern movement (or to its ideological or aesthetic repudiation). Thus, abstract expressionism in painting, existentialism in philosophy, the final forms of representation in the novel, the films of the great auteurs, or the modernist school of poetry [...]: all these are now seen as the final, extraordinary flowering of a high modernist impulse which is spent and exhausted with them.

The State of Things fits this description to perfection, with its apocalyptical discourse on the end of times which Russell (1990:15) has referred to as 'apolitical romanticism'. As is well known, the film was born out of director Wenders's frustrated experience with the making of a neo-noir in Hollywood, where he had been summoned to work by New-Hollywood grandee, Francis 
Ford Coppola, thanks to his auteurist style, but where his exercise of it was thwarted by the producer's own commercial concerns. Thus, the hero in The State of Things, played by the discretely blasé Belgian actor Patrick Bauchau, is Wenders's alter-ego Friedrich (Fritz) Munro, a pun on the names of Fritz Lang and Friedrich Murnau, two legendary German directors who migrated to Hollywood at the turn of 1920 s and 30 . Embodying the sacrificial auteur in the ruthless industrial capital of cinema, Fritz ends up murdered together with his Hollywood producer, Gordon (Allen Goorwitz), who stands for the now defunct American cinema which had been so inspirational to the European new waves. Among New German Cinema directors, Wenders was perhaps the most outspoken American cinema devotee, paying constant homages in his films to the same classical Hollywood directors and B-movie icons enshrined in the auteur pantheon by erstwhile Cahiers du Cinéma writers and Nouvelle Vague filmmakers, under the leadership of François Truffaut. In The State of Things Wenders testifies to this affiliation by means of explicit references to the Nouvelle Vague's foremost self-reflexive director, Jean-Luc Godard, and Contempt (Le Mépris, 1963), Godard's reckoning with and self-affirmation against Hollywood. Indeed, Contempt contains some key elements of The State of Things: the film about a film, here the interrupted screen adaptation of the Odyssey; the presence of Fritz Lang, not just as a citation, but in person, speaking the three languages Wenders claims to be his own comfort zone, German, English and French; a representative from Hollywood, in the person of legendary actor Jack Palance, who embodies the most sordid side of the film industry, including its despicable treatment of women; among other things. Not accidentally, Jameson (2001: 189) lists, under the postmodern category, 'Godard, post-Godard and experimental cinema and video, but also a whole new type of commercial film', as represented, in The State of Things, both by the victimised auteur and the New-Hollywood catastrophe film, The Survivors. From that perspective, Wenders's film, albeit against its own grain, is a salutary swansong of the chain of male geniuses who until very recently constituted the staple of western cinema, including the producers at the head of the Hollywood system; the American directors revered by their French and German new-wave counterparts; and the European auteurs themselves. It was indeed time for them all to retreat to the background and make room for the enormous diversity of films produced around the world with plenty of stories to tell.

Rather than in the film's profuse and often dubious philosophising on the end of times, this chapter is interested in the overflowing of the objective reality beyond the various devices and frames employed to capture it. I shall argue that the emphasis on the 'postmodern' character of The State of 
Things obscures the most positive aspect of its proclaimed death of cinema, namely its realism. The film is first and foremost its real locations in Los Angeles, Lisbon and, in particular, the cliffs around Sintra complete with a monumental modernist seaside hotel half-destroyed by the waves. After stumbling upon this extravagant semi-ruin in Sintra, Wenders is said to have immediately decided to shoot his next film there (Boujout 1986: 99). More than the characters' postmodern reiterations of the end of history and of storytelling, it is the disintegration of this hotel which provides material evidence of the end of the modernist project. The idea of a Europe and its imperial power being irretrievably eroded from the edges, as the sea invades its westernmost extremity, comes across compellingly by means of the camera's careful scrutiny of these locations more than from the lofty verbal quotations to this effect that abound in the film. Depicted as the victory of the objective over the subjective world, the film's realism is entirely in tune with Bazin (2005: 37-38), who defines, about a neorealist film such as Paisan (Paisà, Roberto Rossellini, 1946), what he calls the 'image fact':

[T] he nature of 'image facts' is not only to maintain with the other image facts the relationships invented by the mind [...] Each image being on its own just a fragment of reality existing before any meanings [my emphasis], the entire surface of the scene should manifest an equally concrete density [...] Man himself is just one fact among others, to whom no pride of place should be given a priori.

In tune with more recent non-anthropocentric approaches to film and art, such as critical realism and speculative realism (further elaborated upon in the next chapter), Bazin offers with the concept of 'image facts' a suitable explanation to the chosen imagery in The State of Things, in which realism is directly connected to style, or, in Bazin's (2005: 37) words, to the 'deliberately intended quality in the photography'. In the hands of an aesthete such as French DoP Henri Alekan, and combined with Wenders's own exceptional photographic talent, film itself becomes material presence, not only as landscape, but as apparatus, as its innards are exposed as reflectors, cables, cameras, false background screens, hanging film strips, photographs, drawings, paintings, books, typewriters with blank pages of the stagnant script, computer data and sound recordings. Through the camera's exacting fidelity to its objects, all these are revealed as the pre-existing reality of a (non-)film.

Thanks to this 'pregivenness of the universe to the human' - as Philip Rosen (2003: 57) has defined the Bazinian realist principle - non-cinema, 
as much as the 'postmodern', lends itself, in The State of Things, to a positive reading. In Being and Nothingness, Sartre (2003: 40) explains his negative dialects as follows:

[B]eing is prior to nothingness and establishes the ground for it. By this we must understand not only that being has a logical precedence over nothingness but also that it is from being that nothingness derives concretely its efficacy[...] [N] othingness, which is not, can have only a borrowed existence, and it gets its being from being. Its nothingness of being is encountered only within the limits of being, and the total disappearance of being would not be the advent of the reign of non-being, but on the contrary the concomitant disappearance of nothingness. Non-being exists only on the surface of being.

Sartre's atheistic existentialism is however strongly anthropocentric, as he emphatically declares in Existentialism and Human Emotions (2000: 15):

Atheistic existentialism, which I represent [...] states that, if God does not exist, there is at least one being in whom existence precedes essence, a being who exists before he can be defined by any concept, and that this being is man or, as Heidegger puts it, human reality.

Having drawn upon Sartre's phenomenological ontology for his own realist project, Bazin went on to turn it on its head with regard to cinema, by stating, in his Impure Cinema essay, that 'we must say of the cinema that its existence precedes its essence' (1967: 71). In order to test the application of this thought to our case study, I propose to consider non-cinema as intrinsically dependent, not on the cinema The State of Things has declared dead, but on what preceded it, that is, objective reality.

\section{The State of Things and 'Allusionism'}

The fact that, 30 years on, film in its most various forms and platforms, is still alive and well suggests that the postmodern announcement of the death of cinema, in The State of Things, should not be taken at face value. Suffice it to remember that, rather than providing a closure to Wim Wenders's career, the film is only the twelfth of his prolific production, spanning 39 feature-length titles at the time of writing. Within this long career, peppered with masterpieces and milestones such as Kings of the Road (Im Laufder Zeit, 1976), Paris, Texas (1984), Wings of Desire (Der Himmel über Berlin, 
1987) and Pina (2011), The State of Things stands out as a kind of symbolic capsule. It marks the peak as much as the decline of the New German Cinema, signalling the retreat into obscurity of some of its most illustrious representatives (such as Hans-Jürgen Syberberg), while others, such as Werner Herzog, Volker Schlöndorff and Wim Wenders himself, move on, in the wake of their international success, to greener pastures abroad, i.e. Hollywood in Wenders's case. The film functions as a landmark of this process, offering cinematic expression to a debate first initiated by André Bazin and Gilles Deleuze, which had hitherto been circumscribed to film theory and could be summarised as follows:

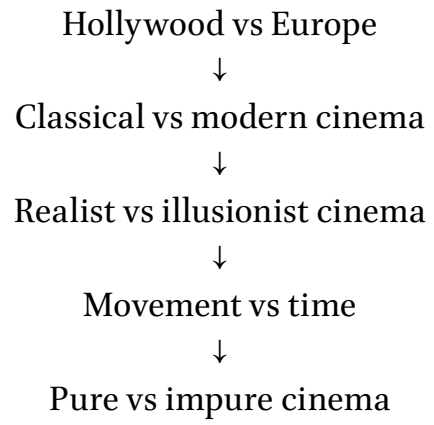

In previous writings (Nagib 2006; 2011; 2012) I have addressed with suspicion these binary oppositions as well as the resulting evolutionist understanding of history and film history that perpetuates the centrality of Hollywood and Europe within world cinema history. Hence the usefulness of the concept of non-cinema, which allows us to transfer the theoretical debate from the outside to the inside of the medium, configuring it as film's constitutive dilemma. Be it covertly, as in conventional narrative cinema, or overtly as in The State of Things, self-negation lies at the heart of the film medium given its time-based properties that allow it to self-present as reality. Non-cinema specimens, such as the films analysed in Part I of this book, recognise and expose this dilemma by striving for an identity with the phenomenological Real, an aim whose impossibility results in a bottomless mise-en-abyme. In the film in focus here, a self-conscious exercise in non-cinema, the film medium is first dismembered into its various constitutive art and medial forms before its final demise, forever inching towards, but never really crossing, its ultimate self-destructive border with real life.

Jean-François Lyotard (1986: 3), the first to theorise on what he calls 'the postmodern condition', dates it back to 'the end of the 1950s, which for Europe marks the completion of reconstruction'. Jameson (2001: 189) 
agrees with the timeframe of 'the end of the 1950s or the early 196os', though questioning whether the artistic movements taking place in that period 'imply any more fundamental change or break than the periodic style- and fashion-changes determined by an older high-modernist imperative of stylistic innovation'. Whatever the case, the mere use of the prefix 'post' implies a teleological and evolutionist understanding of history. By contrast, the idea of non-cinema refers to a non-teleological tendency to self-negate inherent in the medium, which unveils itself as such at cyclical turning points in film history triggered by the 'imperative of stylistic innovation' mentioned by Jameson, which is likely the case of The State of Things. From the late 1970s, Hollywood had become awash with remakes and sequels that recycled both home-made and foreign classics. The period is variously defined as 'New Hollywood', 'postmodern' and 'postclassical', all to signify an increasing dearth of fictional subjects and modes of storytelling. In 1982, the same year The State of Things was released, Noël Carroll (1998 [1982]: 241) published an insightful explanation for the phenomenon, which he referred to as 'allusionism':

Allusion [...] is an umbrella term covering a mixed lot of practices including quotations, the memorialization of past genres, the reworking of past genres, homages, and the recreation of 'classic' scenes, shots, plot motifs, lines of dialogue, themes, gestures, and so forth from film history, especially as that history was crystallized and codified in the sixties and early seventies.

Rather than to a postmodern exhaustion of fictional storytelling, Carroll (241) ascribes allusionism to 'an aggressive polemic of film criticism, often called auteurism', developed in Europe on the basis of the Hollywood classical canon. As a result, according to Carroll, American filmmakers felt motivated to revisit their own film history with renewed attention and to profusely cite from it as well as from those European works that paid homage to them, chiefly from the French Nouvelle Vague, but also from other world new waves.

As one of the most gifted among his New German Cinema peers, Wenders was handpicked in 1978 by Francis Ford Coppola, a central figure within New Hollywood, to conceive and direct a film for his newly-founded film production company, Zoetrope Studios, whose aim was to foster new local and international film talents. The venture should not have meant for Wenders a radical departure from his habitual self-reflexive, meditative filmmaking style, on the contrary, to all appearances, Hollywood was 
opening up precisely to that kind of approach. Wenders was even convinced, at the time, that European cinema, including his own, would be filling in the gap created by the end of the Hollywood B-movie strand, a cheaper and more personal kind of commercial cinema, including the likes of Edgar Ulmer, Howard Hawks and Preston Sturges, who had been inspirational to him (Schütte 2001: 200). He had just come from shooting The American Friend (Der amerikanischer Freund, 1977), a neo-noir adapted from the novel Ripley's Game by American writer Patricia Highsmith, featuring Dennis Hopper, the star and director of the 1969 iconic road movie Easy Rider; and he was about to embark on the shoot of Nick's Film - Lightning over Water (1980), a documentary on the agony and death of director Nicholas Ray, another of his B-movie idols. He was thus ideally placed for the Coppola enterprise.

The plan was again a neo-noir, though not a remake, but a reflexive reassessment of the crime genre as such via the adaptation of Joe Gore's fictional biography of Dashiell Hammett, the private eye turned detective writer that bequeathed to genre cinema one of its most iconic characters, Sam Spade, the protagonist of The Maltese Falcon (John Huston, 1941). Wenders shot a first version of the film in his usual realist style, on location in San Francisco, though not in black and white as he had originally intended. Unfortunately, however, this version seems to have been lost or destroyed. What remains is a disastrous second version, entirely re-shot with a different cast in Coppola's Zoetrope studios, that could perhaps be described as an involuntary film-noir caricature that prefigures the kind of postmodern cinema Tarantino would inaugurate ten years later, but devoid of the latter's irony and humour. This notwithstanding, Wenders's Zoetrope misadventure, stretching over four years, was not entirely wasted, as he managed to produce two independent films in the meantime, in an attempt to set the record straight about his ambiguous relationship with Coppola and Hollywood: the today unavailable Reverse Angle (1982) and the internationally acclaimed The State of Things.

As for the latter, the story goes that in 1981, on one of his trips between Europe and the US, where Hammett had stalled, Wenders stopped over in Sintra, Portugal, to visit his then girlfriend, Isabelle Weingart, an actress in the film The Territory being shot there by Raúl Ruiz. Deceased in 2011, Ruiz (studied in Chapter 6) was a Chilean exile living in France since the mid-1970s, who has to his credit over 100 films and an equal number of theatre plays. Though famous for his uncompromising personal style, Ruiz was also courted by Hollywood in the wake of the 'allusionist' trend, in his case, by Roger Corman, a mentor of some New-Hollywood directors such as Coppola. Corman joined French Nouvelle Vague producer Pierre Cottrell and Portuguese producer Paulo Branco in support of The Territory, 
a Buñuelian allegory of humanity's inherent cruelty, focusing on a group of American tourists who get stranded in a French forest and finally engage in cannibalism. Corman had reportedly advised Ruiz to produce a 'very, very disgusting' film so as to make a 'break into a large United States market' (Kahn 1981: 103). Though certainly extremely violent, the work in progress did not promise any of the graphic gore Corman was probably expecting, so he left the production, and the shoot of The Territory was brought to a halt due to the lack of film stock.

Along came Wim Wenders and, according to some versions, ${ }^{2}$ offered Ruiz his own leftover film stock, but on condition that he could use the whole cast, crew and Portuguese locations of The Territory in a film of his own, which he started to write on the spot and became The State of Things. Accounts diverge here, with Kahn (1981) reporting that, rather than offering succour to Ruiz's endangered production, this was actually completely disrupted with Wenders's arrival on set, forcing Ruiz to return to Paris, reorganise his finances and then resume the shoot of The Territory once Wenders was gone. Ruiz himself never confirmed this version of the events (Martin 1993) and The Territory was eventually completed, though today it is classed under Ruiz's 'rarities' and only remembered for its connection with The State of Things. Indeed, it supplied the latter not only with crew, cast and locations, but also with its central theme, the shoot of a film brought to a halt for lack of film stock and the disappearance of its Hollywood producer. Corman himself makes a brief appearance as the lawyer of Hollywood producer Gordon, the latter, an allusion to Beckett's elusive Godot as well as a parody of Francis Ford Coppola.

In addition, Wenders cast, for the protagonist Fritz, Patrick Bauchau, whom he had found 'wonderful in Eric Rohmer's La Collectioneuse' (Schütte 2001: 199). The choice has further cinephilic (and postmodern) resonances. As Boujut (1986: 99) notes, Brazil's foremost filmmaker and Cinema Novo leader, Glauber Rocha, was in Sintra when Wenders stationed there to shoot The State of Things, and Bauchau, a Rocha fan, took the opportunity to conduct a video-interview with him, in which the latter solemnly declared that 'Sintra is a beautiful place to die', the title-phrase of Bauchau's video interview. Rocha's untimely death would come just a few months thereafter, giving further fodder to the apocalyptic premonitions of the end of cinema in The State of Things. Another Wenders's addition was B-movie icon Samuel Fuller, cast in the role of cinematographer Joe Corby, who appears, with

2 It is entertaining to see producer Paulo Branco (2015) publicly diverging from Wim Wenders on this point during a post-screening Q\&A. 
his unfailing cigar, in another three Wenders films, The American Friend, Hammet and The End of Violence (1997).

Allusionism therefore pervades the film across all its self-reflexive layers. Rather than detracting from its substance, the pre-existence of other film stories, casts, crews and locations responds to those 'image facts' which for Bazin precede the birth of a realist film. Talking a propos of The State of Things, Wenders mentions three types of images: 'grammatical images', which are necessary for the purpose of storytelling; 'profound images', or those that the filmmaker stores in the back of his mind; and 'found images', which are those found in the process of shooting (Russell 1990: 19). The State of Things could be read as a 'found film', in the sense that its point of departure is a collection of pregiven phenomena in the objective world in which humans are condemned to play a secondary role.

\section{In Search of the Real}

The opening scenes in The State of Things, a fragment of the disaster sci-fi in the making, The Survivors, are a citation of the beginning of two Hollywood B-movies, Roger Corman's The Day the World Ended (1959) and Alan Dwan's The Most Dangerous Man Alive (1961), placing the film from the outset within the allusionist trend described above. Following some kind of nuclear disaster, a group of four adults and two children, covered in protective suits and masks, is shown crossing a devastated expanse of land covered in scrap iron, abandoned vehicles, rubble and skeletons. A young girl, wrapped in gauze around her hands and face, moans continuously and is finally choked to death by her own father because she has 'started to melt'. The group proceeds towards the sea, following in the footsteps of previous fugitives, until they arrive at an abandoned hotel half-sunk into the sea, strewn with parts of a crashed airplane.

At this point, the camera angle opens up to unveil the film within the film, by capturing the group of survivors in a real landscape on the left-hand side of the frame, while the right-hand side is occupied by a large canvas containing a landscape painting like those that serve as false background in Hollywood studio sets (Figure 1.1). This pedagogical shot, unveiling the false background that is not being utilised in The Survivors, can only be there to tell us the kind of commercial film Wenders refuses to make, even when shooting on commission from Hollywood. The process of unveiling reality to the spectator proceeds with the sepia tone, hitherto utilised via a day-for-night filter, changing into black and white within a single shot. The 


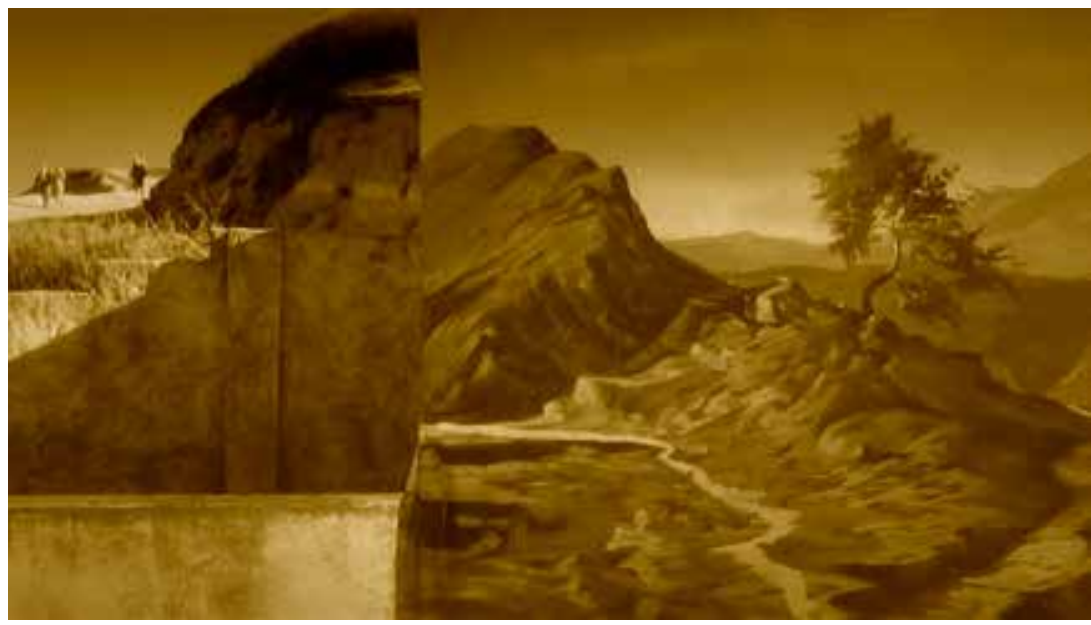

Figure 1.1 The film within the film in The State of Things: a real landscape is on the left-hand side of the frame, while the right-hand side is occupied by a large canvas containing a landscape painting like those that serve as false background in Hollywood studio sets.

'realism' of black and white - defined as such in the film by cinematographer Joe - is thus offered to us didactically, by degrees, so as to demonstrate its superiority over the usual Hollywood colour tricks. By the same token, the soundscape, hitherto dominated by the atmospheric music by Wenders's faithful composer Jürgen Knieper, makes room for the sound of the sea waves which had been muted up to this point.

This is when Hollywood veteran Joe, in a condescending tone to fledgling Fritz, breaks the bad news: stock has run out and the shoot has to stop. This gives Wenders the opportunity to move from the postmodern citational mode back to the modern, or 'Bazinian', search for presentational realism, via a careful survey of the environs and a systematic dismantling of cinema's various constitutive artistic and medial components, in order to test and dismiss, one by one, their mimetic properties. Drawing on some of the casts' real skills, as they retreat to their individual hotel rooms, the camera lingers on their solitary artistic and recording exercises. Actress Joan (Rebecca Pauly) undertakes a scales exercise on her violin with the scores on a stand by the window facing the sea, but she soon stops to retune the strings and start her metronome, in apparent despair at adequately responding to the magnificent seascape. Another, Anna (Isabelle Weingart), takes notes on her diary, but also suddenly stops to cover her dressing-table mirror with a cloth, a scene Russell (1990: 25) reads as an attempt at blocking the cliché of an actor's narcissism in order to give free rein to 'the anti-"story" aesthetic of contingent realism'. The superiority of the Real is confirmed by Fritz's 


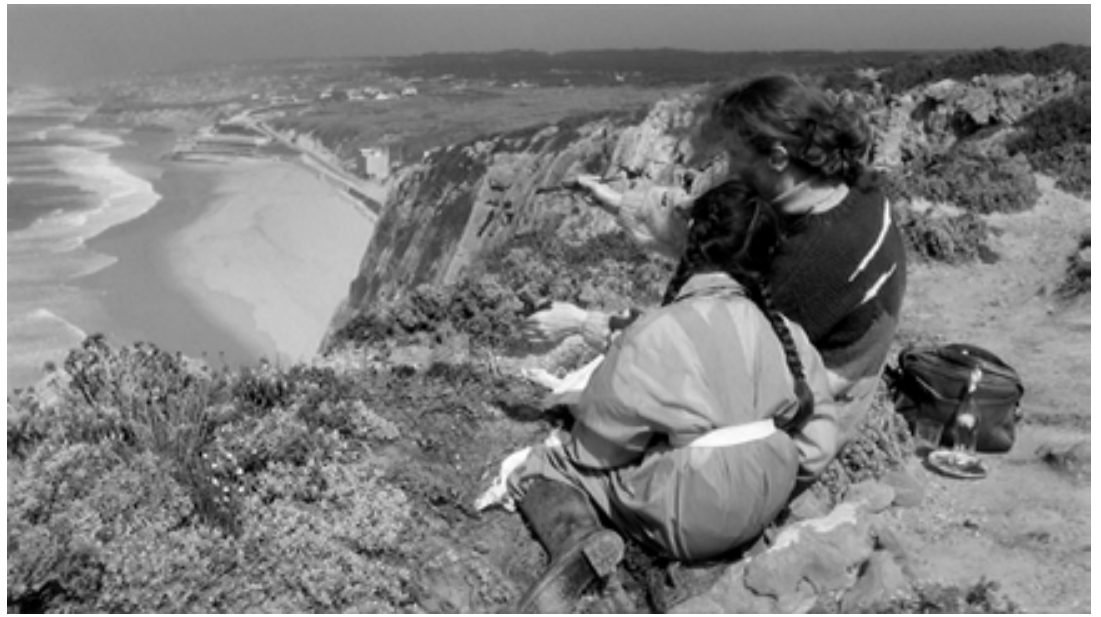

Figure 1.2 Kate, in The State of Things, weeps for being unable to reproduce the dramatic landscape before her eyes in her watercolour painting.

partner and scriptgirl Kate (Viva Auder) in a dialogue line, as she weeps for being unable to reproduce the dramatic landscape before her eyes in her watercolour painting (Figure 1.2). There is even a point when the Polaroid photos, taken by Fritz's daughter Julia and Kate's daughter Jane, displayed on Fritz's bedroom wall, are attacked by nature itself, when a hefty piece of driftwood breaks through the window and a gust of wind blows them away. Still photographs, including the negative film strips hanging on a line in Joe's bedroom, are there to remind us of the material stillness at the base of cinema.

As all these amateur artists fail to communicate their vision of the real, their inconclusive medial activities presage not only the end of the love story between Europe and America, but the end of love tout court. Anna confesses to Mark (Jeffrey Kime), after their first sexual encounter, that she has a sense of déjà vu, while Kate places a drawing of her lover Fritz on his body as he sleeps, and we are offered the two images for comparison: the real-life man and its small, sketchy reproduction complete with the caption: 'I feel like sleeping alone tonight. Kate'. Given the impossibility of relating to an overwhelming reality, love is reduced to onanistic exercises, such as that of Mark in his bathtub and Fritz in his drunken sleep, both of whom have their hands suggestively placed on their lower parts.

Finally, the mechanical and industrial side of cinema comes under scrutiny through the multiplication of gadgets, such as the tape recorder used by Kate as a diary, Joe's voice clock announcing the passing of time minute by minute, multiple photographic and super- 8 cameras, and an 
early Apple computer complete with a small printer kept by scriptwriter Dennis (Paul Getty III) in a derelict Moorish palace on the Sintra outskirts, one of Gordon's neglected properties reminiscent of his former financial glory, where the scriptwriter succumbs to smoking and drinking himself to numbness. The documenting of these mechanical gadgets in connection with the process of filmmaking highlights their impassive materiality which remains untransferable to the film itself.

Unable to reach Gordon by phone, Fritz decides to fly to Los Angeles where he finds him running away from his creditors in a mobile home. His attempt at renewing their friendship ends up with both being shot dead after affectionately hugging and kissing each other. Both cinema and love have indeed become impossible, but Fritz's super-8 camera continues to roll autonomously for a few seconds after his death, finally capturing reality mechanically as it is, free from any subjective will: an incomprehensible blur.

\section{Modern Non-cinema}

Rather than a new phenomenon, the championing of presentational over representational aesthetics in The State of Things responds to a long modernist tradition in political art whose agenda draws on its own rejection as art. Alain Badiou provides us with a useful summary of this tradition, which he addresses in terms of 'inaesthetics'. This refers to the saturation of the three schemata which, in his view, have attempted to define a philosophy of art: didacticism, romanticism and classicism, corresponding respectively to Marxism, Heideggerian hermeneutics and psychoanalysis. For Badiou (2005: 8), modernity is moved by both the didactic and the romantic impulses in its thrust to debunk classicism:

The avant-gardes were didactic in their desire to put an end to art, in their condemnation of its alienated and inauthentic character. But they were also romantic in their conviction that art must be reborn immediately as absolute - as the undivided awareness of its operations or as its own immediately legible truth.

The State of Things follows the same romantic impetus to salvage modern art from its own mistrust in representation. As far as cinema is concerned, Badiou's (82) privileged case study is no other than a Wenders film, The Wrong Movement (Falsche Bewegung, 1975), an adaptation of Goethe's Wilhelm Meister's Apprenticeship (Wilhelm Meisters Lehrjahre), in which 
' $\mathrm{t}]$ he allusive quotation of the other arts, which is constitutive of cinema, wrests these arts away from themselves'. In The State of Things, Kate's failed attempts at reproducing the Real in her drawings and paintings resonate with Badiou's formulation on the avant-gardes' didacticism, in that they draw the viewer's attention to the artwork's representational operations in order to disqualify the copy to the benefit of the thing itself. But they are also romantic in their aspiration for an art that is not distinguishable from its object. Non-cinema may be seen as an offspring of this at once modernist and romantic tradition of self-negation, at the core of which lies the political and ethical aspiration for a legible truth.

Badiou (2005: 10) further observes that '[a] truth is an infinite multiplicity', whereas a 'work of art is essentially finite'. In The State of Things, human presence (as represented by artists attempting to capture objective reality) and truth seem to be mutually exclusive. Martin Lefebvre (2011: 70), citing Simon Schama, states that 'nature may exist without us [...] it doesn't need us, whereas landscape requires some degree of human presence and affect'. Kant (1914) also famously distinguished between the 'beautiful' and the 'sublime', noting that the former refers to the object's form and is limited, whereas the latter derives from a formless, unlimited object, and for this reason human sensibility and imagination are insufficient to fully comprehend phenomena happening in the realm of the sublime. In The State of Things, nature is equally defined as a formless, uncontainable mass, akin to the ineffability of the sublime. This is repeatedly signified through the representation of the act of photographing by imprinting the camera viewfinder on the objects framed so as to demonstrate the photographer's inability to apprehend an object in its overflowing totality (Figure 1.3). Even the monumental, deserted hotel, half-sunk into the sea, where cast and crew are staying, both in the film and in actuality, is posited as a kind of 'frame' destroyed by the force of the nature it attempts to contain (Figure 1.4). The place is in reality the Hotel Arribas, which has now been entirely restored and brought back to its original glory. At the time of the shoot, however, its courtyard, including a magnificent 10om swimming pool made of a section of the sea, was half-submerged in the Atlantic, with its walls partially demolished by the force of the waves.

Nonetheless, if film, together with all the arts and media at its base, is unable to open up a passage to the Real, the realisation of this fact reveals the unquestionable reality of all these expressive mediums, as well as the actual artistic skills of the agents at their helm. Most notably, it is through photography, i.e. by eliciting a sense of stasis and failure and recognising film's inability to capture nature as a whole, that The State of Things gains 


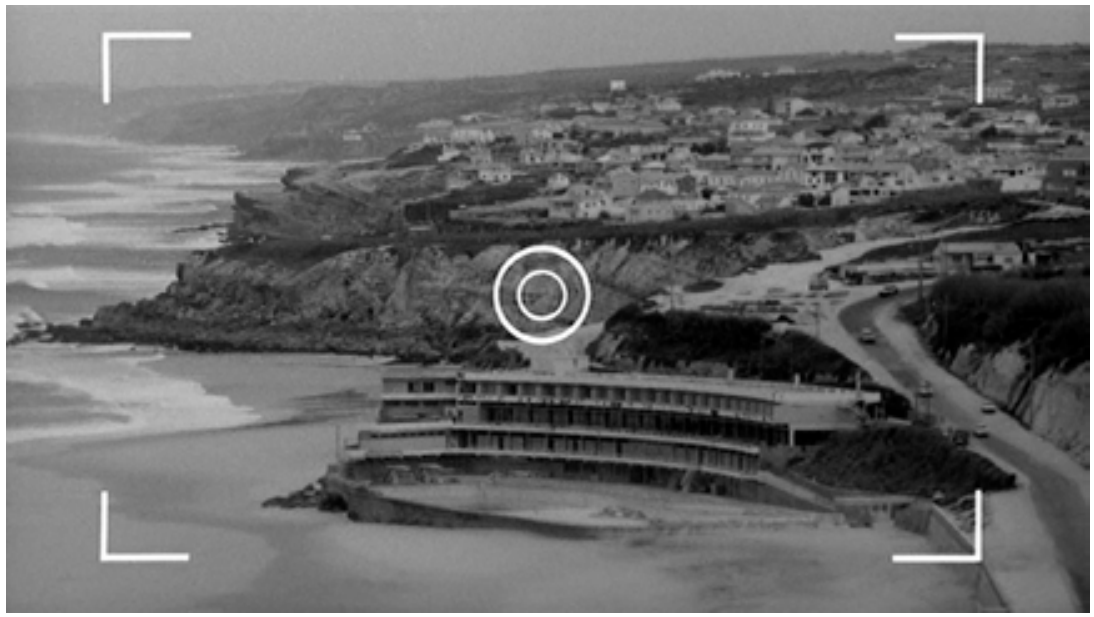

Figure 1.3 The State of Things: the camera viewfinder imprinted on the objects framed demonstrates the photographer's inability to apprehend an object in its overflowing totality.

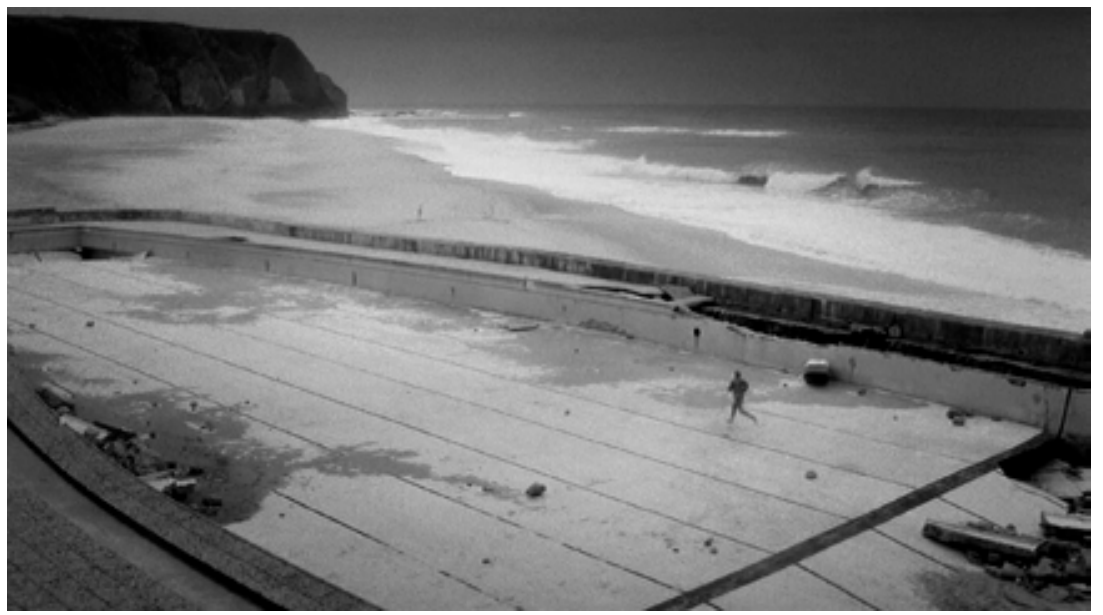

Figure 1.4 The State of Things: the swimming pool in the monumental hotel, half-sunk into the sea, is another kind of 'frame' destroyed by the force of the nature it attempts to contain.

in artistry. It is also in this kind of anti-cinematic stasis that Adorno (1991) saw a way out for cinema, thereby taking issue with Sigfried Kracauer (1997: 33-34), who distinguishes cinema from photography on the basis of movement: the camera movement, the movement of the objects in front of the camera and the movement introduced by montage. Adorno (1991: 180) contends that the centrality of movement in cinema is 'both provocatively denied and yet preserved, in negative form, in the static character of films 
like Antonioni's La Notte'. He says: 'Whatever "uncinematic" in this film gives it the power to express, as if with hollow eyes, the emptiness of time'. Adorno's defence of uncinematic stasis is based on its power to neutralise the unavoidable ideological residues of the culture industry, as symbolised by the quarrel between technology and artistic technique, or, in this case, between Hollywood commerce and auteurist creativity. As Miriam Hansen (2012:218) reminds us, Adorno attributed to cinema a leading role in modern art, but only insofar as it rebelled against its own status as art through self-awareness of its technological origin.

A cinema that gains in artistry by losing its cinematic properties could also be seen as the purpose of Bazin's realist proposal, although here politics decidedly takes a back seat with relation to aesthetics. Bazin's rejection of montage and defence of the long take and the long shot favour the presence in the final film of residues of unexpected phenomena that tend to obstruct narrative progression and are usually removed in the editing process, something that Lyotard (1986b:349) would later formulate in terms of 'acinema'. Bazin is also keen, like Adorno, on 'uncinematic' empty moments, as can be seen in his famous analysis of the coffee-grinding scene in Humberto $D$ (Vittorio de Sica, 1952), in which, according to him, 'nothing happens' (2005: 81-82). In particular, Bazin's concept of 'impure cinema' (1967) dismisses cinema's pretence to medium specificity, highlighting instead its inherent dependence on the other arts.

With its focus on stagnation, endless waiting, lovelessness and inconsequential artistic and medial exercises, The State of Thing constitutes, to an extent, an early candidate for the label of 'slow cinema', popularised in the 200os in reference to a large 'socio-cultural movement whose aim is to rescue extended temporal structures from the accelerated tempo of late capitalism' (de Luca and Jorge 2016: 3). Indeed, in The State of Things, the sense that 'nothing happens', as formulated by Bazin, prevails thanks to the slow editing pace and prodigal use of long takes and long shots. However, things - trivial though they might be - happen all the time in the film, which relies on a montage of suture that weaves together plot and subplot in a seamless chronological progression, climaxing rather conventionally with the protagonist's death. Waiting, as the characters do in this auteurist piece, is also a classical recourse for the construction of suspense, and indeed suspense builds up in particular in the latter part of the film, set in Los Angeles, by means of persecution, spying and even a car chase. Granted, all these elements are metacommentaries on their use in American movies, in which they are aimed at eliciting spectatorial immersion and commercial success. An example is the car chase scene, which contains no speed, crashes 
or dashboard-mounted subjective cameras to enhance the sense of peril. Instead, an extremely high, distant camera captures in a single long shot/ long take combination a car weaving slowly through and around carparks, until it manages to confound and lose its follower, to the delight of the driver. The whole is overlaid with the minimalist score by Jürgen Knieper, whose jazzy beat is here just slightly accelerated, imparting the reassuring sense of a minor event.

The highly accomplished quality of such scenes, and the dazzling images and sounds of the film as a whole, certainly contributed to it being awarded the Golden Lion at the Venice Film Festival in 1982, among a host of other festival prizes. Rather than confirming its own predictions of doom and the end of cinema, it boosted Wim Wenders's career, not just in Europe but also in the United States, where he went on to shoot the highly-acclaimed and Cannes Palme D'Or winning Paris, Texas (1984). These developments expose the limits of categories of modernity and postmodernity, as history went on both in cinema and in general without any traumatic break. Thus the idea of non-cinema, as a periodical wake-up call to film's constitutive dilemma between representation and presentation of reality, may offer a more productive way of situating The State of Things.

\section{Non-cinema as Ruin}

What can and should be taken more seriously than the modern-postmodern divide is the way The State of Things sums up the cinematic challenges and opportunities of its time, and in so doing prefigures not only the 'slow cinema' but also the 'essay film' genre of today, or what Bazin (2005: 97) had called the 'film à thèse'. As Mitchell (1983: 50) states, 'The State of Things is like a fictional film essay of self-assessment'. From the outset, the derelict Hotel Arribas introduces a 'thesis' that cuts across the entire film: the oxymoronic nature of capitalist progress, including its entertainment and tourist industry, whose staleness is constitutive of the novelty it advertises - a fact alarmingly confirmed by the now archaic electronic gadgets littering the film, including a pioneering Apple computer, which is just a little more than a word processer, but displayed in the film as next-generation technology. Invariably and inevitably, the products of these gadgets turn out to be disappointing simulacra. The static and descriptive framings used to produce such an effect constantly bring to the fore cinema's photographic stillness and reinforce the sense of death through stasis, which is corroborated by numerous shots of cinemas in ruins on the streets of Sintra and Lisbon 
and, towards the end, Los Angeles, where a cinema advertising John Ford's The Searchers (1956) is clearly surviving out of past glories. On a similarly metaphorical level, the hotel increasingly engulfed by the sea is recurrently likened to a sinking ship. The character of Robert (Geoffrey Carey) points to a plastic Earth globe and comments: 'Lisbon is really right at the edge, the far-western corner of Europe, indeed there's water right in front of my window'. The metaphor of a sinking ship recurs in the characters' lines, for example, when Fritz reads aloud, to himself, from Alan Le May's book The Searchers (at the origin of Ford's film), about 'the terrible sense of inevitable doom that overpowered him every time he encountered this ship'.

Even more in the spirit of a thesis is the post-catastrophe footage of The Survivors, which could be read as the synthesis of Bazin and Deleuze's vision of modern cinema. Cityscapes in ruins, as epitomised by Berlin in the neorealist film Germany Year Zero (Germania anno zero, Roberto Rossellini, 1947), were hailed by Bazin (2005b: $\left.98 ; 2011: 5^{8-60}\right)$ as the non-anthropocentric symbol of cinematic modernity. Deleuze (2005: 124), like Bazin, dates modern cinema from the end of the Second World War, describing typical postwar film locations as 'any-space-whatevers', made of 'demolished towns [...] vast unused places, docks, warehouses, hips of girders and scrap iron', all of which can be found in the fragment of The Survivors at the beginning of The State of Things. The magnitude of the Second World War, for Deleuze, caused the time-image, typical of modernity, to interfere with and disrupt the action-image he attributes to classical Hollywood and montage cinema in general, creating characters who are observers or 'seers' rather than agents, in a world that overwhelms their comprehension.

Given the recurrence of war in human history, however, there is scope to investigate the combination of ruins and cinema before the Second World War. Indeed, Johannes von Moltke identifies ruins at the very birth of cinema, for example, in the Lumière brothers' The Demolition of a Wall (Démolition d'un mur, 1895), which shows the destruction of a wall and its immediate reconstruction achieved with the simple trick of running the film backwards. For von Moltke (2010: 396), 'this little episode from 1895 might serve as a cinematic epigraph for the broader aesthetic, ontological, and epistemological imbrications of cinema and ruin in modernity'.

In any case, Deleuze's definition of a 'time out of joint' and 'in pure state' is entirely applicable to the representation of Portugal in The State of Things, as it makes use of the country's location at the westernmost end of Europe, that is, at the periphery of Europe's self-attributed modernity, so as to configure it as a kind of space-time hiatus, or a 'time in pure state', that offers a distanced viewpoint to worldly phenomena. Seen in this light, 
the modern and postmodern categories become irrelevant, as they fail to provide reliable indicators of progressive politics. As Jacques Rancière (2009: 51) has pointed out:

If there is a political question in contemporary art, it will not be grasped in terms of a modern/postmodern opposition. It will be grasped through an analysis of the metamorphoses of the political 'third', the politics founded on the play of exchanges and displacements between the art world and that of non-art.

Caught in this dilemma, The State of Things resolves it via non-cinema, that is, by surrendering to film's irresistible drive towards material reality.

\section{Bibliography}

Adorno, Theodor W. (1991), 'Transparencies on Film', in: The Culture Industry, edited and with an introduction by JM Bernstein. London/New York: Routledge, pp. 178-187.

Badiou, Alain (2005), Handbook of Inaesthetics, translated by Alberto Toscano. Stanford: Stanford University Press.

Bazin, André (1967), 'In Defence of Mixed Cinema', in: What Is Cinema? Vol. I, essays selected and translated by Hugh Gray. Berkeley/Los Angeles/London: University of California Press, pp. 53-75.

(2005), 'An Aesthetic of Reality: Cinematic Realism and the Italian School of the Liberation', in: What Is Cinema? Vol. 2, essays selected and translated by Hugh Gray. Berkeley/Los Angeles/London: University of California Press, pp. 16-40.

(2005b), 'In Defense of Rossellini', in: What Is Cinema? Volume 2, essays selected and translated by Hugh Gray. Berkeley/Los Angeles/London: University of California Press, pp. 93-101.

(2011), 'Germany Year Zero', in: André Bazin and Italian Neorealism, edited by Bert Cardullo. New York/London: Bloomsbury, 57-6o.

Boujut, Michel (1986), Wim Wenders. Paris: Edilig.

Branco, Paulo (2015), Post-screening Q\&A with Wim Wenders, available on https:// ww w.youtube.com/watch?v=b1Hkn1ZonrE\&t=3s (accessed 15 July 2019).

Carroll, Noël (1998), 'The Future of Allusion: Hollywood in the Seventies (and Beyond)', in: Interpreting the Moving Image. Cambridge: Cambridge University Press, pp. 240-264. 
de Luca, Tiago and Nuno Barradas Jorge (2016), 'Introduction: From Slow Cinema to Slow Cinemas', in: de Luca and Jorge (eds.), Slow Cinema. Edinburgh: Edinburgh University Press, pp. 1-24.

Deleuze, Gilles (2005), Cinema 2: Time-Image. New York/London: Continuum. Hansen, Miriam Bratu (2012), Cinema and Experience: Siegfried Kracauer, Walter Benjamin, and Theodor W. Adorno. Berkeley/Los Angeles/London: University of California Press.

Jameson, Fredric (2001), 'Postmodernism, or The Cultural Logic of Late Capitalism (1984)', in: Michael Hardt and Kathi Weeks (eds.), The Jameson Reader. Oxford: Blackwell, pp. 188-232.

Kahn, Gred (1981), 'Territorial Rites: Ruiz, Jost and Wenders in Portugal'. Framework: The Journal of Cinema and Media, n. 15/17, Summer, p. 103.

Kant, Immanuel (1914), Kant's Critique ofJudgement, translated with Introduction and Notes by J.H. Bernard, $2^{\text {nd }}$ edition revised. London: Macmillan, available on https://oll.libertyfund.org/titles/kant-the-critique-of-judgement (accessed 15 April 2020).

Kracauer, Siegfried (1997), Theory of Film: The Redemption of Physical Reality. Princeton, New Jersey: Princeton University Press.

Lefebvre, Martin (2011), 'On Landscape in Narrative Cinema'. Canadian Journal of Film Studies, vol. 20, n. 1, Spring, pp. 61-78.

Lyotard, Jean-François (1986), The Postmodern Condition: A Report on Knowledge, translation from the French by Geoff Bennington and Brian Massumi. Manchester: Manchester University Press.

(1986b), 'Acinema', in: Philip Rosen (ed.), Narrative, Apparatus, Ideology: A Film Theory Reader. New York/Chichester: Columbia University Press, pp. 349-359.

Mitchell, Tony (1983), 'Wim Wenders and The State of Things'. Film Criticism, Spring, 7, 3, pp. 47-50.

Nagib, Lúcia (2006), 'Towards a Positive Definition of World Cinema', in: Stephanie Dennison and Song Hwee Lim (eds.), Remapping World Cinema: Identity, Culture and Politics in Film. London: Wallflower Press, pp. 30-37.

- (2011), World Cinema and the Ethics of Realism. New York/London: Continuum.

(2012), Chris Perriam and Rajinder Dudrah, 'Introduction', in: Nagib, Perriam and Dudrah (eds.), Theorizing World Cinema. London/New York: IB Tauris, pp. xvii-xxxii.

- (2016), 'Non-cinema, or The Location of Politics in Film'. Film-Philosophy, 20 (1). pp. 131-148.

Rancière, Jacques (2009), The Emancipated Spectator, translated by Gregory Elliott. London: Verso. 
Rosen, Philip (2003), 'History of Image, Image of History: Subject and Ontology in Bazin', in: Ivone Margulies (ed.), Rites of Realism: Essays on Corporeal Cinema. Durham/London: Duke University Press, 42-79.

Russell, Catherine (1990), 'The Life and Death of Authorship in Wim Wenders' The State of Things'. Canadian Journal of Film Studies, 1, 1, pp. 15-28.

Sartre, Jean-Paul (2000), Existentialism and Human Emotions, translated by Bernard Frechtman. New York: Citadel.

(2003), Being and Nothingness: An Essay on Phenomenological Ontology, translated by Hazel E. Barnes. London: Routledge.

Schütte, Wolfram (2001), 'Goodbye to the Booming Voice of the Old Cinema: The State of Things', conversation with Wim Wenders, in: Wim Wenders: Essays and Conversations. London: Faber and Faber, pp. 197-209.

von Moltke, Johannes (2010), 'Ruin Cinema', in: Julia Hell and Andreas Schönle (eds.), Ruins of Modernity. Durham, NC: Duke University Press, pp. 395-417. 
